\section{Ornamental Grass Tolerance to Postemergence Grass Herbicides}

\author{
Joanna Hubbard ${ }^{1}$ and Ted Whitwell ${ }^{2}$ \\ Department of Horticulture, Clemson Universiy, Clemson, SC 29634
}

Additional index words. Calamagrostis, Cortaderia, Eragrostis, Erianthus, Miscanthus, Sorghastrum, Spartina, Panicum, Pennisetum, fenoxaprop-ethyl, fluazifop-P, sethoxydim, herbicide tolerance

\begin{abstract}
Twelve ornamental grasses from the genera Calamagrostis, Cortaderia, Eragrostis, Erianthus, Miscanthus, Sorghastrum, Spartina, Panicum, and Pennisetum were evaluated for tolerance to the postemergence herbicides fenoxaprop-ethyl, fluazifop-P, and sethoxydim at $0.4 \mathrm{~kg}$ a.i./ha. Calamagrostis was uninjured by fenoxaprop-ethyl as measured by visual injury ratings, height, and foliage dry weight. Greenhouse studies evaluated the tolerance of three Calamagrostis cultivars to fenoxaprop-ethyl rates of 0.4 to $3.2 \mathrm{~kg}$ a.i./ha with no observed visual injury from any treatment. However, the expansion rate of the youngest Calamagrostis leaf was reduced linearly with increasing herbicide rates each day after application. The highest rate $(3.2 \mathrm{~kg}$ a.i./ha) reduced the leaf expansion rate by 1 day and all other rates by 3 days after treatment. Leaf expansion rate differed between Calamagrostis cultivars at different times after herbicide treatment. Dry weight of Calamagrostis arundinacea 'Karl Foerster' was reduced at 4 weeks after treatment but not at 10 weeks after treatment. Chemical names used: ( \pm )-ethyl 2-[4-[(6-chloro-2-benzoxazolyl)oxy)phenoxy]propanoate (fenoxaprop-ethyl); (R)-2-[4-[[5-trifluoromethyl)-2-pyridinyl $]$ oxy]phenoxy]propanoic acid (fluazifop-P); 2[1-(ethoxy imino)butyl]-5- [2-(ethylthio)propyl]-3-hydroxy-2-cyclohexen-1-one (sethoxydim).
\end{abstract}

Ornamental grasses have increased in popularity because of their great versatility and low maintenance requirements. Annual and perennial grass weeds and encroachment of turfgrass species, such as bermudagrass [Cynodon dactylon (L.) Pers], are major problems in landscape establishment and commercial production of ornamental grasses. Lttle information is available about ornamental grass tolerance to herbicides and this information relates only to preemergence herbicides (Glaze et al., 1980; Neal and Senesac, 1991).

Cyclohexanedione (sethoxydim) and two aryl-oxy-phenoxy propionic acids (fenoxaprop-ethyl and fluazifop-P) are postemergence herbicides for control of annual and perennial grasses. Fenoxaprop-ethyl, fluazifop-P, and sethoxydim consistently control the annual weeds crabgrass (Digitaria spp. ) and goosegrass [Eleusine indica (L.) Gaertn.] (Baron and Monaco, 1985; Chernicky et al., 1984; Lewis, 1985). Turfgrass species demonstrate a differential tolerance to fenoxaprop-ethyl and sethoxydim. Tall fescue (Festuca arundinacea Schreb.), bentgrass (Agrostis palustris Huds.), and bermudagrass are tolerant to fenoxaprop-ethyl (Higgins et al., 1987; McCarty et al., 1989),

\footnotetext{
Received for publication 17 Sept. 1990. Technical contribution 3159 of the South Carolina Agricultural Experiment Station. The cost of publishing this paper was defrayed in part by the payment of page charges. Under postal regulations, this paper therefore must be hereby marked advertisement solely to indicate this fact.

'Graduate Student.

${ }^{2}$ Professor.
}

and fenoxaprop-ethyl is labeled for grass weed control in bluegrasses (Poa spp.), fescues (Festuca spp.), perennial ryegrass (Lolium perenne L.), and zoysiagrass (Zoysia spp.). Sethoxydim is not phytotoxic to centipedegrass [Eremochloa ophiuroides (Munro) Hack.] (McCarty et al., 1986) and is labeled for use in established and seedling turfgrass. In St. Augustinegrass [Stenotaphrum secundatum (Walt.) Kuntze], bahiagrass (Paspalum notatum var. saurae Parodi), and centipedegrass, reduction in foliar dry weight correlated with susceptibility to sethoxydim and fluazifop-P (Willard et al., 1990). Differential tolerance to these herbicides also may exist for ornamental grass species. Sethoxydim, fenoxaprop-ethyl, and fluazifop-P are labeled for control of weedy grasses in many ornamental trees, shrubs, and herbaceous plants and would, therefore, be useful for grass control in ornamental grass plantings if tolerance could be determined. The objective of this research was to evaluate the tolerance of diverse ornamental grass species to single applications of postemergence grass herbicides.

Twelve ornamental grasses (Table 1) were propagated by division and field-planted in May 1989 on an amended Cecil series (clayey, kaolinitic, thermic Typic Hapludults) at the Clemson Botanical Gardens, Clemson, S.C. Each plot consisted of 12 individual plants in a randomized complete block design with three replications. The site was fertilized with $1220 \mathrm{~kg} \cdot \mathrm{ha}^{-1} 5 \mathrm{~N}-4 \mathrm{P}-5 \mathrm{~K}$ before planting and plants were drip-irrigated daily. Herbicide treatments were fenoxaprop-ethyl (F-E), fluazifop-P (F-P), and sethoxydim (SETH) at $0.4 \mathrm{~kg}$ a.i./ha and an untreated control
(CONT). F-E and F-P spray mixtures contained $0.5 \%$ (v/v) Triton Ag-98 (alkylaryl polyoxyethylene glycols; Rohm and Haas, Philadelphia) and SETH treatments $1.25 \%$ (v/v) Dash (BASF Wyandotte Corp., Parsippany, N.J.). Treatments were applied across the top of grasses 5 weeks after planting using a $\mathrm{CO}_{2}$ backpack sprayer delivering 190 liters $\cdot$ ha $^{-1}$ At this time, newly expanded leaves were visible and grass height varied between 35 and $95 \mathrm{~cm}$ (Table 1). Visual injury ratings (percent) and height measurements were made at weekly intervals, and foliage was harvested 10 weeks after treatment (WAT) and fresh weights recorded. Visual injury was estimated on a percentage scale of $\mathrm{O}$ to $100 \%$ with $\mathrm{O}=$ no injury and $100 \%=$ complete kill. Foliage was dried for 7 days at $65 \mathrm{C}$ and dry weights per plant were recorded. All data were subjected to analysis of variance and means separated using least significant differences at $\boldsymbol{P}=0.05$.

Calamagrostis arundinacea 'Karl Foerster' was determined to be tolerant to F-E at $0.4 \mathrm{~kg}$ a.i./ha in the field study; therefore, a rate study was initiated to determine the response of Calamagrostis to increasing rates of F-E. Three ornamental Calamagrostis cultivars, Calamagrostis arundinacea (L.) Roth 'Karl Foerster', Calamagrostis arundinacea ssp. brachytricha (Steud.) Tzvel., and Calamagrostis xacutiflora (Schrad.) Reichb. 'Stricta', were propagated by division and potted in 3.6-liter containers in commercial potting media (Fafard Co., Anderson, S.C.). Plants were fertilized with $473 \mathrm{~N}-206 \mathrm{P}-392 \mathrm{~K}$ ppm in the irrigation water for 2 weeks before treatment and irrigated as needed after treatment. Plants were grown in a glasshouse under natural daylength supplying up to $1400 \mu \mathrm{mol} \cdot \mathrm{m}^{-2} \cdot \mathrm{s}^{-1}$ photosynthetic photon flux at plant level. F-E rates of $\mathrm{O}$, $0.4,0.8,1.6$, and $3.2 \mathrm{~kg}$ a.i./ha containing $0.5 \%$ Triton Ag-98 (v/v) were applied by use of a $\mathrm{CO}_{2}$ backpack sprayer that delivered 190 liters $\cdot \mathrm{ha}^{-1}$. A randomized complete block design with four single-plant replications was used and the experiment was repeated. Experiment 1 was initiated in Nov. 1989 and Expt. 2 in Jan. 1990. Length of the youngest expanding leaf at time of herbicide application was measured before treatment and at daily intervals for 5 days. Two leaves per plant were measured and growth rate for the first 5 days after treatment (DAT) calculated. Foliage was harvested 10 weeks (Expt. 1) and 4 weeks (Expt. 2) after treatment, dried for 7 days at $65 \mathrm{C}$, and dry weights per pot recorded. Visual evaluations of percent injury were made throughout the course of the experiments. All data were subjected to analysis of variance; since differences for the experiments were similar, data were combined. Growth rate response to herbicide rate and DAT was determined using linear regression analysis for overall trends and the least significant difference test for specific mean comparisons.

Most ornamental grasses exhibited maximum injury 4 weeks after herbicide treat- 
Table 1. Taxonomic and common names and height at time of treatment of ornamental grasses in field studies.

\begin{tabular}{llr}
\hline \hline Taxonomic name & \multicolumn{1}{c}{ Common name } \\
\hline Calamagrostis arundinacea (L.) Roth cv. Karl Foerster & Karl Foerster's Feather Reed Grass & Ht (cm $\pm \mathrm{SE})^{z}$ \\
Cortaderia selloana (Schult.) Asch \& Graebn. & Pampas Grass & $50 \pm 3$ \\
Eragrostis curvula (Schrad.) Nees & Weeping Love Grass & $35 \pm 4$ \\
Erianthus ravennae (L.) Beauv. & Ravenna Grass & $50 \pm 3$ \\
Miscanthus sinensis Anderss. & & $95 \pm 5$ \\
$\quad$ Gracillimus & Maiden Grass & $85 \pm 3$ \\
Purpurascens & Purple Leaved Miscanthus \\
Varicgatus & Variegated Silver Grass \\
Panicum virgatum L. cv. Haense Herms & Red Switch Grass \\
Pennisetum alopecuroides (L.) Spreng. & Fountain Grass \\
Pennisetum setaceum (Forsk.) Chiov. cv. Rubrum & Crimson Fountain Grass \\
Sorghastrum nutans (L.) Nash & Indian Grass & 30 \\
Spartina pectinata Link cv. Aureomarginata & Varicgated Cord Grass & $70 \pm 2$ \\
\hline
\end{tabular}

Table 2. Visible injury (percent) and height (in centimeters) of ornamental grasses 4 weeks after herbicide treatment at $0.4 \mathrm{~kg}$ a.i./ha and visible injury and foliage dry weight 10 weeks after treatment.

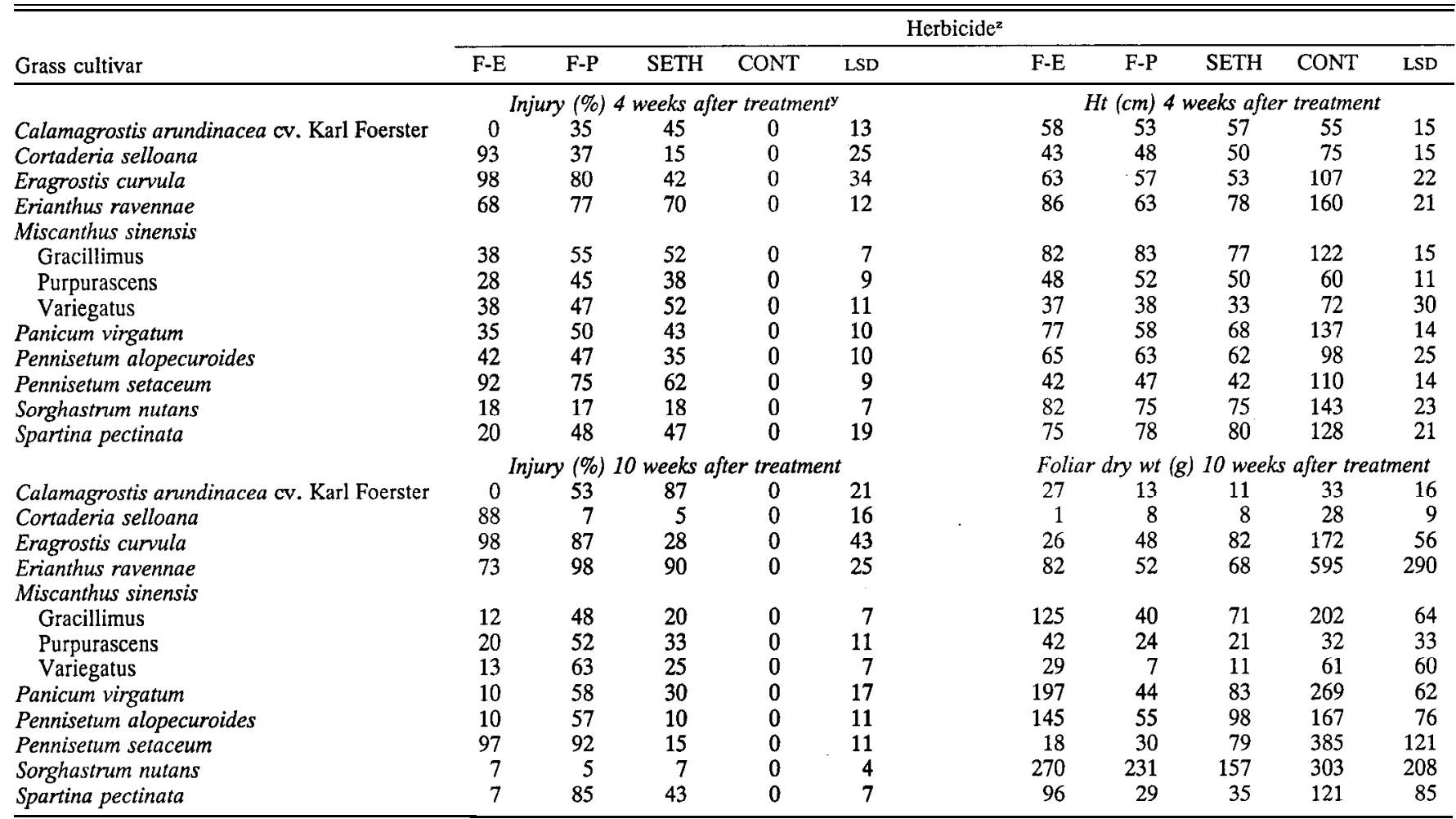

${ }^{\mathrm{x}} \mathrm{F}-\mathrm{E}=$ fenoxaprop-ethyl, F-P = fluazifop-P, SETH = sethoxydim, CONT = nontreated control; LSD at $P=0.05$.

y Visible injury was rated on a scale of 0 to $100 \%$, with $0=$ no injury and $100 \%=$ complete kill.

ment (Table 2). Injury symptoms consisted of chlorosis and necrosis of young foliage that spread to older parts of the plant; necrosis of shoot meristems; red pigmentation of foliage in some species, such as Panicum virgatum; and cessation of growth. No visual injury was observed for F-E on Calamagrostis arundinacea and only minimal injury was noted for SETH on Cortaderia selloana. Height reduction 28 DAT was observed for all treated grasses except for F-P and SETH on Miscanthus sinensis 'Purpurascens' and all herbicides on Calamagrostis arundinacea. Immediately before harvest, 10 weeks after treatment, significant injury was still evident on the majority of grasses, although only minimal injury was observed from SETH on Eragrostis curvula, F-E on $P$. virgatum and Spartina pectinata, SETH and F-E on Pennisetum alopecuroides, and SETH and F-P on Cortaderia selloana. Only minimal injury was observed from all herbicides on Sorghastrum nutans and no injury resulted from F-E treatment on Calamagrostis arundinacea.

Treated and nontreated $M$. sinensis 'Purpurascens', $M$. sinensis 'Variegates', and S. nutans had similar foliage dry weights. Foliage dry weights of Calamagrostis arundinacea, $P$. alopecuroides, and S. pectinata at 10 weeks were reduced only following F-P and SETH treatments. Herbicide treatments caused reduced dry weights of all other species compared to the controls.

Calamagrostis arundinacea showed no injury symptoms following F-E application and did not differ from nontreated plants in height or dry weight. These data indicate that Calamagrostis arundinacea is tolerant to F-E at the rate tested. All other grasses evaluated were either visibly injured or growth was reduced by the herbicides. Researchers have reported injury, height reduction, and dry weight reduction as a result of postemergence grass herbicide treatment of other grass species (Willard et al., 1990). Tolerance of several turfgrass species to postemergence grass herbicides has also been reported, with tall fescue, bentgrass, and bermudagrass being tolerant to F-E (Higgins et al., 1987; McCarty et al., 1989) and centipedegrass being tolerant to SETH (McCarty et al., 1986).

In the greenhouse study, no injury was observed on any of the Calamagrostis cultivars at any rate of F-E, indicating that these species are highly tolerant to F-E. The highest herbicide rate represents nearly 10 times the normal use rate of F-E, indicating at least a 10-fold tolerance of Calamagrostis cultivars. The growth rate of the youngest leaf was analyzed by regression over days after treatment with no significant linear response 
Table 3. Expansion rate of the youngest leaf of Calamagrostis (combined data from Calamagrostis anundinacea 'Karl Foerster', C. $\times$ acutiflora 'Stricta', and C. aurndinacea spp. brachytricha) for the first 5 days after treatment with fenoxaprop-ethyl.

\begin{tabular}{|c|c|c|c|c|c|}
\hline \multirow{3}{*}{$\begin{array}{l}\text { Rate } \\
\text { (kg a.i./ha) }\end{array}$} & \multicolumn{5}{|c|}{$\begin{array}{l}\text { Expansion rate } \\
\left(\mathrm{mm} \cdot \mathrm{day}^{-1}\right)\end{array}$} \\
\hline & \multicolumn{5}{|c|}{ Day after treatment ${ }^{z}$} \\
\hline & 1 & 2 & 3 & 4 & 5 \\
\hline 0 & 30.1 & 25.5 & 30.9 & 25.8 & 27.5 \\
\hline 0.4 & 27.7 & 23.8 & 24.1 & 17.8 & 22.5 \\
\hline 0.8 & 28.0 & 23.7 & 25.4 & 18.5 & 22.8 \\
\hline 1.6 & 27.7 & 23.1 & 23.8 & 17.4 & 19.4 \\
\hline 3.2 & 26.0 & 22.6 & 24.9 & 17.4 & 19.7 \\
\hline Response $^{\mathbf{y}}$ & $\mathrm{L}$ & $\mathrm{L}$ & $\mathrm{L}$ & $\mathrm{L}$ & $\mathrm{L}$ \\
\hline \multicolumn{6}{|l|}{ LSD } \\
\hline$(P=0.05)$ & 3.4 & 2.6 & 3.7 & 3.6 & 3.9 \\
\hline
\end{tabular}

${ }^{z}$ There was not significant response to time after treatment.

y Linear (L) response.

for any species. Analysis of variance for the growth rate of the youngest leaf revealed no treatment $\mathrm{x}$ grass interaction, so data for all three cultivars were combined for each treatment (Table 3) and for all herbicide treatments (excluding the nontreated control) for each grass (Table 4). Growth rate of the youngest leaf of Calamagrostis was reduced linearly by increasing rates each day after application. The highest rate $(3.2 \mathrm{~kg}$ a.i./ha) of F-E reduced the growth by 1 and 2 DAT, while all rates restricted the growth rate compared to the nontreated on subsequent days (Table 3 ).

Analysis of variance for the daily expansion rate of the nontreated grass cultivars showed no significant differences between cultivars (data not shown). Therefore, differences in daily expansion rate can be attributed to differing sensitivity of Calamagrostis cultivars to F-E. 'Stricta' had the highest growth rate for each day after herbicide treatment, with the exception of 4 DAT (Table 4), and 'Karl Foerster' had the lowest growth rate each day after treatment. Brachytricha had an intermediate growth rate response, except for 4 DAT when it had the highest growth rate.

No reduction in foliage dry weight was observed for 'Stricta' and brachytricha at 4 or 10 WAT (data not shown). However, all rates of F-E reduced the dry weight of 'Karl Foerster' at 4 WAT, but the reduction was nonlinear (Table 5). It is possible that 'Karl
Table 4. Expansion rate of the youngest leaf of Calamagrostis anundinacea 'Karl Foerster', $C$. $\times$ acutiflora 'Stricta', and $C$. anundinacea spp. brachytricha for the fitst 5 days after treatment with fenoxaprop-ethyl (combined data from application rates of $0.4,0.8,1.6$, and $3.2 \mathrm{~kg}$ a.i./ ha).

\begin{tabular}{lccccc}
\hline \hline & \multicolumn{4}{c}{$\begin{array}{c}\text { Expansion rate } \\
\left(\mathrm{mm} \cdot \text { day }^{-1}\right)\end{array}$} \\
\cline { 2 - 5 } & \multicolumn{4}{c}{ Day after treatment } \\
\cline { 2 - 6 } Species & 1 & 2 & 3 & 4 & 5 \\
\hline C. arundinacea & & & & & \\
cv. Karl Foerster & 26.6 & 22.6 & 21.1 & 14.6 & 18.6 \\
$\begin{array}{l}\text { C. } \times \text { acutiflora } \\
\text { cv. Stricta }\end{array}$ & 30.1 & 25.4 & 24.7 & 17.3 & 23.4 \\
C. arundinacea & & & & & \\
Spp. brachytricha & 25.3 & 21.9 & 27.8 & 21.5 & 21.3 \\
LSD $(P=0.05)$ & 2.8 & 2.3 & 3.2 & 3.2 & 3.3 \\
& & & &
\end{tabular}

Foerster' plants were able to recover so that dry weight was not reduced at 10 WAT. Therefore, although all three Calamagrostis cultivars appeared visually to be tolerant to F-E, growth of the youngest leaf was inhibited. 'Stricta' appears to be the most tolerant to F-E and 'Karl Foerster' the most sensitive, with brachytricha exhibiting intermediate tolerance.

The greenhouse study shows Calamagrostis to be tolerant to F-E, at $\approx 10$ times the normal use rate. Vegetable plants have been reported to be injured by postemergence grass herbicides in the greenhouse but not in the field (Boucounis et al., 1988), which may be explained by the positive correlation of absorption of these herbicides with higher relative humidity and temperature in the greenhouse environment (Harrison and Wax, 1986; Kells et al., 1984). Based on the field and greenhouse studies, F-E could be safely used for grass weed control in greenhouse production and outdoor plantings of Calamagrostis. Several grasses in the field study recovered from earlier herbicide injury based on dry weight measurements and percent injury evaluations at 10 WAT. Sequential application of postemergence grass herbicides may be necessary to control grassy weeds that germinate throughout the growing season, thus tolerance of ornamental grasses to sequential herbicide applications needs to be studied.

\section{Literature Cited}

Baron, J.J. and T.J. Monaco. 1985. The influence of stage of growth of three grass species on
Table 5. Foliage dry weights per pot of Calamagrostis anundinacea 'Karl Foerster' 4 and 10 weeks after treatment (WAT) with fenoxapropethyl (F-E).

\begin{tabular}{lcc}
\hline \hline \multirow{2}{*}{$\begin{array}{l}\text { Rates } \\
\text { (kg a.i./ha) }\end{array}$} & \multicolumn{2}{c}{ Dry wt $(\mathrm{g})$} \\
\cline { 2 - 3 } & 4 WAT & 10 WAT \\
\hline 0 & 8 & 12 \\
0.4 & 5 & 14 \\
0.8 & 6 & 12 \\
1.6 & 6 & 13 \\
3.2 & 6 & 14 \\
Response & NS & NS \\
LSD $(P=0.05)$ & 1 & 1 \\
\hline
\end{tabular}

${ }^{\mathrm{z}}$ No linear response (NS).

phytotoxic effect of five postemergence grass herbicides. Weed Sci. Soc. Amer. Abstr. 25:104.

Boucounis, T.G., T. Whitwell, and W.L. Ogle. 1988. Growth of five vegetable crops treated with the herbicide fluazifop in a greenhouse. HortScience 23:771.

Chernicky, J.P., B.J. Gossett, and T.R. Murphy. 1984. Factors influencing control of annual grasses with sethoxydim or RO-13-8895. Weed Sci. 32:174-177.

Glaze, N. C., M. Singh, and S.C. Phatak. 1980. Response of pampas grass and two azalea cultivars to alachlor, oxadiazon and oxyfluorfen. Proc. Weed Sci. Soc. Amer. 20:41-42.

Harrison, S.K. and L.M. Wax. 1986. Adjuvant effects on adsorption, translocation and metabolism of haloxyfop-methyl in corn (Zea mays). Weed Sci. 34:185-195.

Higgins, J. M., L.B. McCarty, T. Whitwell, and L.C. Miller. 1987. Bentgrass and bermudagrass putting green turf tolerance to postemergence herbicides. HortScience 22248-250.

Kens, J.J, W.F. Meggitt, and D. Penner. 1984. Absorption, translocation, and activi!y of fluazifop-butyl as influenced by plant growth stage and development. Weed Sci. 32:143-149.

Lewis, W.M. 1985. Fenoxaprop-ethyl for smooth crabgrass and goosegrass control in turf. Proc. Southern Weed Sci. Soc. 38:104.

McCarty, L. B., J.M. Higgins, L.C. Miller, and T. Whitwell. 1986. Centipedegrass tolerance to postemergence grass herbicides. HortScience 21:1405-1407.

McCarty, L. B., J.M. Higgins, T. Whitwell, and L.C. Miller. 1989. Tolerance of tall fescue to postemergence grass herbicides. HortScience 24:309-311.

Neal, J.C. and A.F. Senesac. 1991. Preemergent herbicide safety in container-grown ornamental grasses. HortScience 26:157-159.

Willard, T. R., C.M. Peacock, and D.G. Shilling. 1990. Photosynthesis as an index of turfgrass growth following application of herbicides. HortScience 25:451-453. 